\title{
A discussion about health psychology and palliative care in brazil
}

\begin{abstract}
Health Psychology proposes a paradigm change in health care, since it considers health and disease as the result of a complex integration of biopsychosocial factors. In this sense, the health psychologist would have much to contribute as part of a palliative care staff. Thus, this paper aims to discuss the role of the health psychologist in palliative care in Brazil. It is pointed out that, in Brazil, Health Psychology is not a consolidated field and, on the other hand, Hospital Psychology is recognized and in constant expansion. This fact reinforces the focus on tertiary/hospital care, and makes it difficult for this professional to enter the field of palliative care. Suggestions to enhance this insertion are pointed out.
\end{abstract}

Keywords: health psychology, palliative care, brazil
Volume I Issue 5 - 2017

\author{
Tagma Marina Schneider Donelli, Elisa Kern \\ de Castro \\ Universidade do Vale do Rio dos Sinos, Brazil
}

Correspondence: Tagma Marina Schneider Donelli, Universidade do Vale do Rio dos Sinos - UNISINOS, São Leopoldo, RS, Brazil,EmailTAGMAD@unisinos.br

Received: September 29, 2017 | Published: November 06, 2017

\section{Introduction}

Health Psychology intends to understand health and illness from the integration and articulation of biomedical and psychological knowledge, and is part of a paradigm shift that is still ongoing and that sees health and illness as an integration of bio psychosocial factors. ${ }^{1-4}$ In this sense, the health psychologist has a lot to contribute to the palliative care team, especially with regard to increasing well-being and reducing the suffering of patients and their families, as well as working with the health team itself. ${ }^{5}$ Therefore, the transformation of health care with the participation of the psychologist makes all the patients with serious illnesses have access to a more qualified care.

\section{Palliative care and health psychology in brazil}

The first reports on palliative care in Brazil date back to the 1980 s in the public health system, but only in 2005 there was significant progress with the creation of the National Cancer Care Policy. ${ }^{6}$ However, the implantation and consolidation of palliative care face the difficulty that, historically, the pattern of health care was centered in the hospital, hindering alternative models of care. In this perspective, the advent of palliative care creates the need for a paradigm shift in the care offered to patients who no longer respond to curative interventions: the management of pain and psychological, social and spiritual manifestations becomes a priority. ${ }^{7}$ The psychologist and other professionals whose practices contribute to achieving these goals are consequently gaining space in health teams. Nevertheless, when considering the activity of psychologists in the health area in Brazil, it is important to look for aspects that may hinder their insertion. There is no consolidated area called Health Psychology in the country. On the other hand, Hospital Psychology is a recognized and constantly expanding area. The Brazilian Federal Psychology Council itself recognizes the area of Hospital Psychology, but not the internationally known area of Health Psychology. Hospital Psychology itself is curious, as Brazil is the only country that has recognized an area of expertise for the psychologist based on the place of work ${ }^{4}$ since $2001 .^{8}$ In 2016, ${ }^{9}$ another area was created by the Brazilian Federal Psychology Council, Psychology in Health. Its definition aims to approach the traditional area of Health Psychology, but it is more related to work in the public sector. Therefore, there are no clear movements of Psychology in Brazil that will remind us of the importance of palliative care in health, since the focus is on tertiary care - hospital - and on the social perspective of basic health care.

Thus, there are few research or experience reports that address the role of the health psychologist in palliative care in Brazil. ${ }^{10}$ Even when it is addressed, the work of the psychologist is not expressed clearly, that is, how it is developed and how the psychologist can act. ${ }^{11,12}$ On the other hand, doctors also have difficulty introducing the psychologist in palliative care. A study among oncologists performed in Brazil found that there are difficulties for these professionals to perform an interdisciplinary and integrated work and, even when they perceive the importance of referring patients for psychological treatment, their criteria for deciding whether or not to refer are unclear and depend on a certain intuition of the doctor about the patient's pain. ${ }^{13}$ That means to say that, it is difficult to establish teamwork that characterizes palliative care and that includes the health psychologist.

\section{Conclusion}

Based on what was presented, it is noticed that there are still obstacles to the activity of the psychologist in health teams in palliative care. First, there is still some confusion about which the health psychologist is and the role the health psychologist has in teams that do not target curative treatments. This difficulty is the result of a historical confusion about the activity of the psychologist in health, and could be minimized with greater investment in the training of this professional. In addition, the impact of the psychologist's work in palliative care teams has still been little explored in research, which directly affects the production of knowledge and evidence that may support such practices. In order to change this scenario, it is suggested that training and practice with evaluation of health interventions should be allied, in an attempt to clarify the role of the psychologist and contribute effectively to the purpose of palliative care.

\section{Acknowledgements}

Tagma Marina Schneider Donelli and Elisa Kern de Castro like to thank $\mathrm{CNPq}$, from the Brazilian federal government, for its support in drafting this work. 


\section{Conflict of interest}

The author declares no conflict of interest.

\section{References}

1. Adler RH. Engel's biopsychosocial model is still relevant today. $J$ Psychosom Res. 2009;67(6):607-611.

2. Engel GL. The need for a new medical model: a challenge for biomedicine. Science. 1977;196(4286):129-136.

3. Matarazzo JD. Behavioral health and behavioral medicine: frontiers for a new health psychology. Am Psychol. 1980;35(9):807-817.

4. Castro EK de, Bornholdt E. Psicologia da saúde x psicologia hospitalar: definições e possibilidades de inserção profissional. Psicol Ciênc Prof. 2004;24(3):48-57.

5. Kasl-godley J, King D a, Quill TE. Opportunities for psychologists in palliative care: working with patients and families across the disease continuum. Am Psychol. 2017;69(4):364-376.

6. Fonseca A, Fini D. An Overview of Brazilian palliative care. Hosp Palliat Med Int J. 2017;1(3):1-2.
7. Pereira da Silva E, Sudigursky D. Concepções sobre cuidados paliativos: revisão bibliográfica. Acta Paulista de Enfermagem. 2008;21(3):504508.

8. https://site.cfp.org.br/wp-content/uploads/2006/01/resolucao2001_2.pdf

9. https://site.cfp.org.br/wp-content/uploads/2016/04/ Resolu\%C3\%A7\%C3\%A3o-003-2016.pdf

10. Ribeiro Hermes H, Arruda Lamarca IC. Cuidados paliativos: uma abordagem a partir das categorias profissionais de saúde. Ciência \& Saúde Coletiva. 2013;18(9).

11. Porto AR, Fripp JMC, Arrieira ICO. Palliative care: a look at the experience in southern Brazil. Hosp Palliat Med Int J. 2017;1(3):17.

12. Porto G, Lustosa MA. Psicologia hospitalar e cuidados paliativos. Rev da Soc Bras Psicol Hosp. 2010;13(1):76-93.

13. Menna-Barreto S, Castro EK de. Critérios de médicos oncologistas para encaminhamento psicológico em cuidados paliativos. Psicol Ciênc Prof. 2015;35(1):69-82. 